\title{
Resettlement Caused by Jatigede Dam Project -Consequence of Long Delayed Implementation of a Project
}

\author{
Opan Suhendi Suwartapradja \\ Department of Anthropology, Faculty of Social and Political Science \\ Universitas Padjadjaran \\ E-mail: opan.s.suwartapradja@unpad.ac.id \\ Ryo Fujikura \\ Faculty of Sustainability Studies, Hosei University, Japan \\ E-mail: fujikura@hosei.ac.jp
}

Sunardi (Corresponding author)

Graduate Program of Environmental Studies Universitas Padjadjaran

J1. Sekeloa Selatan 1, Bandung 40132, West Java Province, Indonesia

E-mail: sunardi@unpad.ac.id

Regina Hoi Yee Fu

Faculty of Economics, Senshu University, Japan

Email: the0954@isc.senshu-u.ac.jp

Received: January 10, 2019 Accepted: February 2, 2019 Published: February 28, 2019

doi:10.5296/jad.v5i1.14422 URL: https://doi.org/10.5296/jad.v5i1.14422

\begin{abstract}
Jatigede dam was constructed in Sumedang Regency of West Java Province, Indonesia. It was planned as early as the 1960s. The World Bank cancelled its financing for the reason of
\end{abstract}


insufficient resettlement planning in 1986, but land acquisition for the dam continued and cash compensation was provided to affected villagers. In spite of the suspension of land acquisition in 1997, the Chinese Government became the new sponsor and dam construction started in 2005. Inundation began in 2015 and the villagers were resettled mainly to the vicinity of the reservoir. The construction was completed in 2015. Most of the cash compensation was provided during the mid-1980s. As three decades have passed since the provision of the compensation, resettlers who received the money conceived that the dam construction project has been cancelled. They spent the money at their original place and did not invest for the resettlement. Today, most of the resettlers are jobless and poor. Their incomes are below the international poverty line. Aquaculture at the reservoir is one of the possible options to improve local economy, but the local government prohibits it to avoid deterioration of water quality.

Keywords: Jatigede dam, Indonesia, resettlement, compensation

\section{Introduction}

Demand for agricultural water and electric power is rapidly increasing in developing countries as population grows and living standards improve. Large multipurpose dam is one of the possible options to address the two issues at the same time. There are many dam projects planned in developing countries. Nevertheless, large dams involve a large number of resettlement. While the exact number of displaced people due to dam construction is unknown, World Commission on Dams (WCD) estimated it to be 40 million to 80 million (WCD, 2000).

Livelihood reconstruction of resettlers is always a difficult task. Two theoretical frameworks that give a basis for dam-induced displacement can guide us in considering existing challenges in displacement and resettlement practice in developing countries. The first one is the Four-Stage Framework developed by Thayer Scudder, which "theorized on how the majority of resettlers can be expected to behave during a successful resettlement process" (Scudder, 2005: 31). The four stages are: Planning and Recruitment Stage (first), Adjustment and Coping (second), Community Formation and Economic Development (third), and Handing Over and Incorporation (fourth) (Scudder, 2005: 29-44). The second one, the "Impoverishment Risks and Reconstruction Model", was developed by Michael Cernea (Cernea, 1997). He led the World Bank's social development work, and developed the model based on his field experience with World Bank projects. Cernea's work is seen by some not only as a theoretical framework, but also as a practical tool for planning compensation and resettlement. It offers other aid agencies and developing countries to a useful tool for planning and implementing compensation and resettlement programs in a systematic and standardized way.

Following accumulation of resettlement experiences, the development of resettlement plan has gradually improved, but there is still much room for further improvement. The central issue is to help resettlers secure an income after relocation. It is often unsuccessful; adequate alternative land is not provided to farmers, resettlement areas are not developed as promised, vocational training is not provided. It is important to provide vocational training and secure 
secondary sources of income for the resettlers. Emotional attachment of the first generation to the submerged land is also a difficult issue to be addressed. The number of affected families which will move to remote areas are often overestimated by the dam developers. A lot more of people than expectation choose to live near the dam reservoir because of emotional attachment to their original land, causing lack of farm land to be provided. Careful assessment of the impact on the resettlers and their participation into formulation of resettlement plan is crucial (Fujikura and Nakayama, 2015).

This study investigates the situation of life reconstruction of resettlers displaced by Jatigede dam construction project in Java, Indonesia. Regarding the resettlement, some researchers have conducted studies based on interviewing resettlers and literature survey. Moeliono (2011) reviewed the historical background of the Jatigede dam project and the provision of compensation to the resettlers. Sugiarti (2017) conducted a survey on 88 affected families, indicating that relocation had caused a huge change in the lives of residents. She reported that 77 out of the 88 households were engaging in jobs other than agriculture, and that there was no unemployed household. Wiryawan (2017), on the other hand, surveyed 75 affected families, presenting that $88 \%$ of them were unemployed and the monthly incomes of $75 \%$ of them were less than 700,000 rupiah. More than $90 \%$ of the resettlers felt that the socio-economic condition was getting worse. Likewise, Bayu et al. (2018) interviewed 125 affected families, community leaders, and officers of related organizations. They found that many of the resettlers became unemployed.

In the next section, the history of Jatigede dam project is briefly reviewed. Resettlement situation is then revealed based on the census surveys conducted in 1992, 2000, and 2016. In the end, the results are evaluated and possible options to improve the situation are discussed.

\section{History of Resettlement}

Jatigede dam is a multi-purpose rock-fill dam constructed at Cimanuk River in Sumedang Regency of West Java Province (Figure 1). Its total capacity is 980 million cubic meters and has a catchment area of 1,462 square kilometers. It has a reservoir of 41.22 square kilometers. Hydropower capacity of Jatigede dam is $110 \mathrm{MW}$. Construction of the dam began in 2007 and completed in 2015. Hydropower operation will be commenced in 2019. 


\section{MInstitute Macrothink $^{\text {Ins }}$}

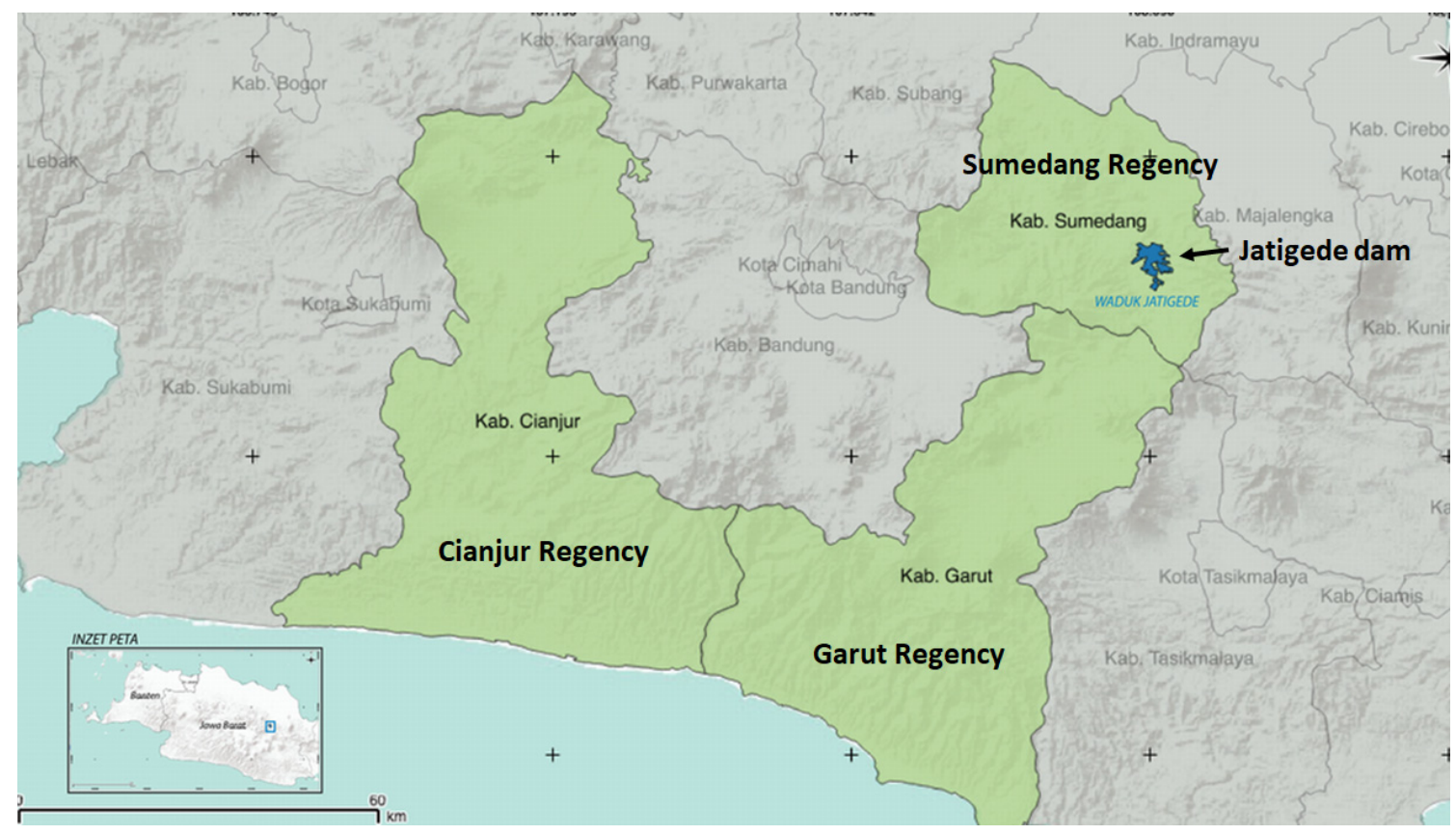

Figure 1. Location of Jatigede dam

The history of Jatigede dam resettlement is summarized in Table 1. The dam construction project was planned and a geological survey was conducted as early as the 1960s. In 1963, a Dutch consultant company recommended the dam construction (Moeliono, 2011). However, in 1982 the World Bank recommended to the Indonesian Government that the construction should be "indefinitely postponed" due to "unfavorable foundation conditions at the dam site and GOI's decision not to construct large dams in Java" (World Bank, 1982). The government, despite the opposition, began land acquisition from 1982. By 1986, 4,065 households had accepted the resettlement (Wiryawan, 2017). In those days, people opposing a national project or disagreed with compensation offered by the government were regarded as hinderers of national development. Some people were even summoned to the regional military tribunal (Moeliono, 2011). There were three choices for the resettlers; 1) participating in national transmigration program to relocate outside of Java, 2) moving to outside of the dam development area (translocation), and 3) settling around the reservoir (Institute of Ecology, 2000). During 1984 - 1991, 911 out of 6,642 households chose to join the transmigration, but 121 of them again returned to the vicinity of the reservoir within the same period (Institute of Ecology, 1992). 
Table 1. Chronology of the Jatigede dam resettlement

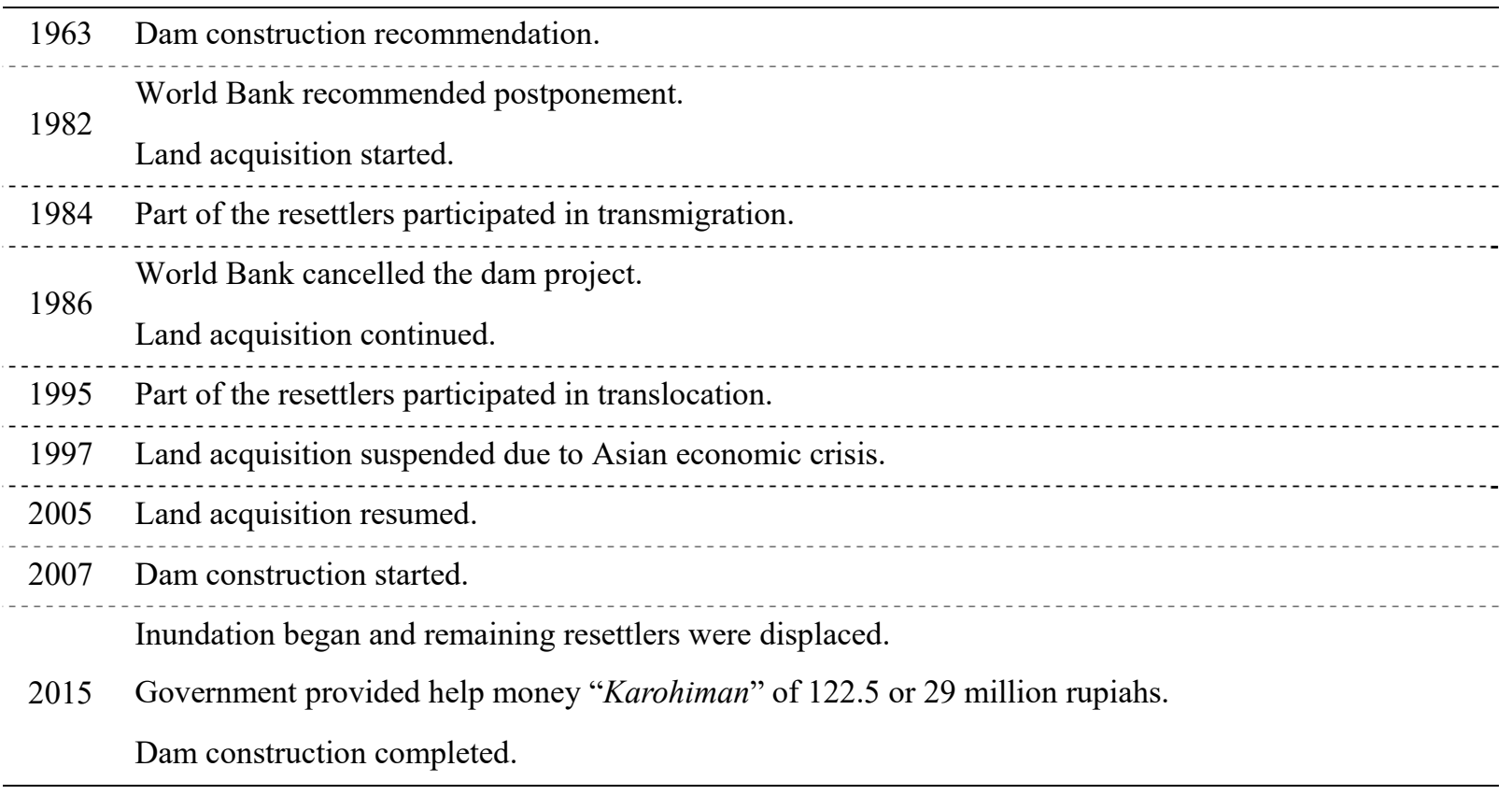

Cash compensation was 6,000 rupiahs (about 5.9 USD) (Note 1) per one Tumbak land (equivalent to $14 \mathrm{~m}^{2}$ ). It was supposed to have been provided during $1984-86$, but $50.8 \%$ of the 5,686 households that had moved to three major resettlement districts (Darmaraja, Wado, and Jatinunggal) answered in 2000 that they still had not received the money (IOE, 2000). Before the final payment of the compensation, the government allowed the resettlers to continue farming within the project area even after they received the compensation. The resettlers later found that the amount of compensation was insufficient for them to buy equivalent farmland at their new destinations. The government lent land owned by 5 districts (i.e. Leuwi Hideung, Wado, Padajaya, Cipaku, and Sukakersa) of Sumedan Regency. Resettlers were allowed to build houses on these government lands without renting the land. The government also promised the resettlers to provide other supports, but have never realized them. Meanwhile, the construction project did not proceed. The resettlers perceived that the dam might not be actually built and that they could further stay at their original land. They spent the cash compensation at their original place instead of investing for the future resettlement (Natahadibrata, 2015). Some of those who had moved returned to the vicinity.

In 1986, an Australian consultant firm conducted another position survey to promote the project (Bayu et al., 2018). The World Bank, however, did not answer to the proposal and decided not to finance the dam project due to fund shortage and insufficient resettlement plan. The World Bank mentioned that "the resettlement study which was added to this component left several important questions unanswered," and concluded that it "was impracticable to finalize any resettlement plans until it was announced whether the construction would actually be proceeded" (World Bank, 1989). Despite the withdrawal of the World Bank, land acquisition was continued until 1997 when the Asian economic crisis occurred.

Because only a small number of resettlers chose transmigration, translocation within West 


\section{Macrothink

Java Province was proposed in 1995. As a result, 96 families and 400 families moved to Garut Regency and Cianjur Regency, respectively. Both sites were close to Sumedang Regency (Figure 1). However, the dam construction did not start even after the resettlement was completed. Afterwards, 6 of the 96 families in Garut Regency and all of the 400 families in Cianjur Regency returned back to their place of origin. They resumed cultivation on their original land, assuming that the dam would not be actually built. Table 2 shows the number of households which lived within the project area. Size of the area was 3,240 ha covering 17 villages of 3 districts (Cadasngampar, Wado, and Darmaraja). The number of households reduced from 6,646 to 5,686 during 1991 - 2000. Some households had moved out by their own decision during the period (IOE, 2000).

Table 2. Number of households living in the areas to be submerged

\begin{tabular}{lrr}
\hline Year & 1991 & 2000 \\
\hline Cadasngampar & 772 & 798 \\
Wado & 1,710 & 1,688 \\
Cadasngampar & 4,064 & 3,200 \\
\hline Total & 6,546 & 5,686 \\
\hline
\end{tabular}

Source: IOE, 2000.

In 2005, the Yudoyono administration became active in infrastructure construction through the introduction of foreign capital, and land acquisition for the Jatigede dam was resumed in 2006. In 2007, the Chinese Government concluded a loan agreement of US \$ 239.57 million with the Indonesian Government as a construction cost. Sinohydro, a Chinese construction company, received the construction permit. Construction work began in 2007. Submerging was finally started in 2015 and those living and cultivating the land were displaced within a short period of time. Out of 3,886 households, 3,828 (98.5\%) answered that they were forced to move (Academic Leadership Grant, 2016).

The number of resettlers actually moved to vicinity of the reservoir was 3,886 households as of 2016. They scattered in four districts of Darmaraja, Wado, Jatinunggal, and Jati Gede in Sumedang Regency (Table 3). Majority of the remaining resettlers also moved to neighbor districts within Sumedang Regency. The only urban area among the destinations was Sumedang Utara. Only a small number of resettlers moved outside of Sumedang Regency. 
Table 3. Number of households who moved to vicinity of the reservoir

\begin{tabular}{lcc}
\hline District & No. of Villages & No. of Households \\
\hline Darmaraja & 11 & 2,099 \\
Wado & 5 & 1,070 \\
Jatinunggal & 2 & 381 \\
Jati Gede & 2 & 336 \\
\hline Total & 20 & 3,886 \\
\hline
\end{tabular}

Source: Academic Leadership Grant, 2016.

In 2015, the year of forced displacement, the government provided additional money; 1) to 4,154 households with 122.5 million rupiahs (about 9,000 USD) and 2) to 6,410 households with 29 million rupiahs (about 2,200 USD) (Note 2). The former group had moved during 1982 - 86, and the latter group in 1993 (Wiryawan, 2017). The money was not provided as compensation but as "help" (Karohiman) for (1) house demolition/unloading, (2) living for 6 months, and (3) renting house for 6 months. "The government created the impression that compensation was not a right, but a benevolent gift from the government". (Moeliono, 2011). The difference between 122.5 million and 29 million was granted as a kind of reward for earlier resettlement.

Resettlers built their houses using their own money adding to the money provided by the government. Only limited infrastructure was provided to the resettlers by 2018. Clean water service was not provided. Resettlers had to establish the water facility by themselves. Water shortage is serious during dry season. They are forced to walk a long distance to find water springs or rivers. No new health clinic was constructed for the resettlers. They are only located at district centers. Those living in villages far from the district centers have to go to village policlinics managed by obstetricians. Primary/secondary schools were built only at selected villages with more than 100 families. Senior high schools are located only at district/regency centers.

\section{Situation of the Resettlers}

The average monthly income per capita of 360 households within the project area was 136,510 rupiah in 2000. As the average number of family was calculated as $3.4(19,542$ person for 5,686 households in 2000), the average daily income per capita was 1,338 rupiah (about 0.28 international dollar, PPP) (Note 3), which was far below the international poverty line of 1.09 dollar. The average land ownership of dry land, paddy field, garden and pond of 1,714 households were 116, 22, 12 and $9 \mathrm{~m}^{2}$, respectively. They were apparently in very poor economic situation (IOE, 2000). In July 2016, the monthly income of 3,862 households (99.4\%) was below one million rupiah (Academic Leadership Grant, 2016), equivalent to 0.84 international dollar per day per capita (PPP) (Note 4). It should be noted that this figure was not the average income and that the income of most of the resettlers were still below one million rupiah. It could hardly be concluded that the economic situation of the resettlers had 


\section{Macrothink}

Journal of Asian Development

ISSN 2377-9594 2019, Vol. 5, No. 1

improved. Except the study of Sugiarti (2017), the vast majority of residents were reported to be in unemployment status. Table 4 shows the occupations before and after relocation. Many resettlers, who answered as "Housewife" before the resettlement, changed their answers into "Unemployed" after resettlement. If "Housewife" and "Unemployed" were summed up as household with no job, the number increased from 3,058 to 3,634 (93.5\%). Most of the resettlers were too poor to choose any option other than moving back to the vicinity of the reservoir, and that made the situation even worse.

Table 4. Occupation of the resettlers

\begin{tabular}{lrr}
\hline Occupation & Before & After \\
\hline Housewife & 1804 & 188 \\
Unemployed & 1254 & 3446 \\
Farm owner & 334 & 10 \\
Farm labor & 126 & 20 \\
Seller/Tradesman & 117 & 37 \\
Civil servant & 54 & 12 \\
Private employees & 39 & 36 \\
Day worker & 38 & 43 \\
Self-employed & 29 & 20 \\
Factory labor & 28 & 28 \\
Teacher & 16 & 3 \\
Craftsmen & 15 & 11 \\
Others & 32 & 27 \\
\hline Total & 3,886 & 3,886 \\
\hline
\end{tabular}

Source: Academic Leadership Grant (ALG), 2016.

Executing agencies did not seem to have conducted vocational training for resettlers. Among 1,087 households, 378 of them (34.8\%) wanted to have training of fishery (Table 5). Quite a few migrants wished to conduct fishing at the newly formed reservoir but most of them were actually jobless. 


\section{Macrothink}

Table 5. No of resettlers who would like to have vocational training

\begin{tabular}{lc}
\hline Type of Training & No of families \\
\hline Fisheries & 378 \\
Self-employment & 315 \\
Farming & 183 \\
Stockbreeding & 119 \\
Trading & 37 \\
Pastry making & 31 \\
Eco-tourism & 13 \\
Boat making & 9 \\
Catering & 2 \\
\hline Total & 1087 \\
\hline
\end{tabular}

Source: Academic Leadership Grant (ALG), 2016.

\section{Discussion}

It can be concluded that the economic situation of resettlers was hardly better-off after resettlement. The major reason was the suspension of dam construction for many years. Cash compensation was provided mostly during mid-1980s. The construction actually started in 2007 and the land inundated in 2015, which was 30 years after the compensation payment. It was natural that the resettlers conceived the cancelation of the project. They felt that it was unnecessary to move anymore and spent the money at their original places. They were too poor to save money for the unseen future. When they were notified to move, they had no money to invest for the resettlement. Help money (Karohiman) provided in 2015 was too little to support their resettlement.

World Bank's Operational Manual, OP4.12 - Involuntary Resettlement stipulates that, "the implementation of resettlement activities is linked to the implementation of the investment component of the project to ensure that displacement or restriction of access does not occur before necessary measures for resettlement are in place" (World Bank, 2001). Asian Development Bank's Involuntary Resettlement Safeguards also stipulates that, "for timely implementation of a project and to avoid cost overruns and delays, it is important that borrowers/clients remain focused on the project timeline and resettlement work" (ADB, 2012: para 148). In the Jatigede dam case, delay of resettlement was extremely long, and the resettlement plan, if there was any, should have been fundamentally reviewed and revised. Cash compensation should have been paid before the actual resettlement regardless the resettlers had received it or not during the 1980s.

In addition to the delay of the resettlement, there are some issues to be taken into consideration to facilitate life rehabilitation of resettlers. They include (1) Formulation of resettlement plan, (2) Forms of resettlement compensation, (3) Implementation of resettlement plan, (4) Supplementary income sources, (5) Educational environment, and 
(6)Attachment to the land (Fujikura and Nakayama, 2015).

(1) Formulation of resettlement plan

The World Bank cancelled funding for the Jatigede dam construction project in 1989 as a result of inadequacy of resettlement plan. Since then no substantial improvement of the plan was conducted. It was unlikely that resettlers had ever participated in the formulation of the plan. Many resettlers said that they were forced to move in 2015 within a short period of time. As a result, very few facilities and infrastructure, including water supply facility, road, and clinics were provided in the new destinations.

(2) Forms of resettlement compensation

OECD (1992) and the World Bank (2001) recommended compensation of land equivalent to submerged land rather than cash. On the contrary, the Indonesian Government conducted cash compensation, and actually provided the resettlers with cash. Given the high population density in Java Island and resettlers' emotional attachment to their home, securing enough land would be very difficult. Cash compensation might be an easier alternative for the government. However, the compensation price $\left(6,000\right.$ rupiahs per $\left.14 \mathrm{~m}^{2}\right)$ was not enough as resettlers were too poor and had only small land plots. As written above, cash compensation should have been provided again just before the actual resettlement, and the amount should have been increased to appropriate level for the resettlers to be better-off. If it was difficult to increase the amount, additional supports including vocational training should have been provided.

(3) Implementation of resettlement plan

Apparently no substantial resettlement plan was formulated until the actual resettlement was implemented. During the mid-1980s when the cash compensation was provided, the government promised to give additional supports other than cash. It was not revealed what kind of support had ever been planned, but if it was done after the actual resettlement, the present situation of resettlers would at least be slightly improved.

(4) Supplementary income sources

Fish farming with floating net cage (FNC) at the reservoir is a promising option for job creation. One successful example is the fish farming and processing by resettlers from the submerged area of Koto Panjiang Dam in Sumatra Island, Indonesia. They have succeeded significantly in raising incomes. They do not need to use the reservoir but dug their fish culture ponds (Karimi and Taifur 2013).

A similar case is found close to Jatigede dam. When the World Bank was studying Jatigede dam during the 1980s, it funded a project of Saguling dam in the neighboring Bandung. The dam construction was completed in 1987. World Bank proposed fish farming at the reservoir as a mean to create jobs for resettlers. However, outsiders came in and floated too many FNCs on the reservoir. The surface covered was too large, which caused severe deterioration of lake water quality and sharply decreased fish catch (Manatunge et. al. 2009, Sunardi et. al. 2013). In case of Jatigede dam, if fish farming had been exclusively permitted to the resettlers 
and if enough funds had been provided to invest in FNCs, the resettlers would have also increased their income as those in Koto Panjiang.

Unfortunately, the West Java Province government prohibits the use of FNC at Jatigade reservoir, and plans to institutionalize the restriction. They have a concern that deterioration of water quality caused by excessive farming would damage turbines of the generator. Ironically, the government aims to promote tourism by fishing. They have already released 4 million fish, and will finally release a total of 10 million (Nurulliah 2016). Wiyanti (2017) agreed that tourism could create jobs for resettlers. However, as the relocation happened in a sudden, infrastructure has not yet been developed. Tourism should not be easily regarded as a solution to promise economic development of the region.

Promotion of tourism is a long-term task and will not contribute to immediate life reconstruction of resettlers. From the experiences of Saguring dam and Koto Panjiang dam resettlement, fish farming using FNCs may be recommended as an immediate measure. If fish farming is exclusively permitted for the resettlers, and guidelines on feeding methods and number of FNCs are formulated for sustainable fish farming, it will contribute to the successful reconstruction of their life.

(5) Educational environment

Primary/secondary schools are built only at selected villages. Senior high schools are located only at district/regency centers. Further improvement of educational environment would increase satisfaction of the resettlers. Improvement of educational environment is one of the keys to increase satisfaction of the resettlers as they are generally very keen to give their second generation a higher education. Resettlers from the Ikawa dam constructed in Japan during the 1950s felt that their lives were not improved economically, but resettlers were satisfied that the second generation had been able to receive a higher education (Takesada, 2009). As for the second generation of residents who resettled in the urban areas from the Bili-Bili dam in Indonesia, 42 percent of young persons in their twenties had obtained university education, and some were even enrolled in graduate school. Primary and secondary schools were established at every resettlement village for the resettlers of Nam Theun 2 dam constructed during the 2000s (Fujikura and Nakayama 2015).

(6) Attachment to the land

Resettlers' attachment to their original land is generally very strong in Indonesia. They wish to live near the lake as much as possible. It is difficult to make them move to remote locations. When Saguling dam was constructed, 2,000 out of the 10,644 affected households were expected to participate in transmigration, with 2 hectares of farmland and a house provided free of charge. However, only 74 households actually participated, and most of the resettlers moved to the surrounding area of the reservoir causing shortage of land to be provided (Nakayama 1998). Regarding the Jatigede dam project, only 911 households $(3,978$ people) chose the option of transmigration, and at least 121 households (525 people) returned to the surrounding area of the reservoir. Most of the resettlers who chose translocation proposed in 1995 and moved to neighbor regencies had also returned. As the result, the 
number of resettlers concentrated around the reservoir became much higher than expected. The government was unable to provide agricultural land to the relocated people as in the Saguling case, resulting in keeping them in severe poverty. Taking the emotional aspect and land availability of Jatigede project into consideration, cash compensation is probably a better option than land compensation.

\section{Acknowledgements}

The research carried out for this study was partly supported by KAKENHI (16H03320).

\section{References}

Academic Leadership Grant. (2016). Pemukiman Kembali Orang Terkena Dampak Waduk Jatigede (The Resettlement of People Affected by Jatigede Dam Development), Faculty of Social and Political Science and Directorate for Research, Community Service and Innovation (DRPMI), Padjajaran University, Indonesia.

Asian Development Bank. (2012). Involuntary Resettlement Safeguards, Asian Development Bank

Bayu, K., Nugraha, D., Kusniadi, E., Nurfadilah, A., \& Wisoso A. (2018). An impact analysis of Jatigede dam project affected people on economic, social and culture, Journal of Built Environment, Technology and Engineering, 4, 15-24.

Cernea, M. (1997). Risks, Safeguards and Reconstruction: A Model for Population Displacement and Resettlement, World Development, 25(10), 1569-1587. https://doi.org/10.1016/S0305-750X(97)00054-5

Fujikura, R., \& Nakayama, M. (Editor) (2015). Resettlement Policy in Large Development Projects. Routledge, Oxford

Institute of Ecology (IOE). (1992). Analisis Dampak Lingkungan Waduk Serbaguna Jatigede (Environmental Impact Assessment of Jatigede Multipurpose Reservoir). Institute of Ecology, Ministry of Public Works. Bandung, Indonesia.

Institute of Ecology (IOE). (2000). Studi Minat Secara Mengelompok Penduduk Terdampak Waduk Jatigede (Study of People Affected by Jatigede Dam Development). Ministry of Public Works. Bandung, Indonesia.

Karimi, S., \& Taifur. (2013). Resettlement and development: a survey of two of Indonesia's Koto Panjang resettlement villages. International Journal of Water Resources Development, 29(1), 35-49. https://doi.org/10.1080/07900627.2012.739539

Moeliono, T. P. (2011). Chapter IX Land Acquisition in the Public Interest: The Jadigete Hydroelectric Powr plant case, Spatial Management in Indonesia: From Planning to Implementation Cases from West Java and Bandung A socio-legal study (Doctor Thesis, Leiden University, pp.283-301).

Nakayama, M. (1998). Post-project Review of Environmental Impact Assessment for Saguling Dam for Involuntary Resettlement, Water Resources Development, 14(2), 217-229. 
https://doi.org/10.1080/07900629849411

Natahadibrata, N. (2015). Long-awaited Jatigede Dam to start operation in July. The Jakarta Post, June 11, 2015.

Nurulliah, N. (2016) Cages in Jatigede Prohibited, Spreading 10 million Fish (Indonesian). Pikiran Rakyat, 17 February 2016.

OECD Development Assistance Committee. (1992) Guidelines on Aid and Environment, OECD.

Scudder, T. (2005). The Future of Large Dams: Dealing with Social, Environmental, Institutional and Political Costs, Earthscan: London.

Sugiarti, A. L. (2017) The Relationship of the Jatigede Dam Construction towards Socio-Economic Conditions on Farming Community in the District of Jatigede-Sumedang, International Research Journal of Education and Sciences, 1(Special Issue 2), 15-20.

Takesada, N. (2009) Japanese Experience of Involuntary Resettlement: Long-Term Consequences of Resettlement for the Construction of the Ikawa Dam, International Journal of Water Resources Development, 25(3), 419-430. https://doi.org/10.1080/07900620902965459

Wiyanti D. T., Suwartapradja O. S., \& Nurseto, H. E. (2017) A Success or A Failure: Adaptive Strategy of Affected People in Jatigede Dam Tourism Program, Proceedings of the International Conference on Education, Psychology, and Social Sciences (Volume 4, pp. 256-261).

Wiryawan B. A. (2017). Social Impact of Jatigede Dam construction, IAIA Symposium, Manila 20-22 February 2017.

World Bank. (1982). Report and Recommendation of the President of the Intrnational Bank for Reconstruction and Development to the Executive Directors on a Proposed Loan to the Republic of Indonesia for the Sixteenth Irrigation Project. World Bank.

World Bank. (1989). Project Completion Report, Indonesia Sixteenth Irrigation Report (Loan 2118-IND). World Bank.

World Bank. (2001). Operational Manual, OP 4.12 - Involuntary Resettlement. World Bank.

World Commission on Dams. (2000). Dams and Development - A New Framework for Decision-Making. Earthscan: London.

\section{Notes}

Note 1. Exchange rate of USD currency in the 1980s was about 1,025 IDR to 1 USD.

Note 2. Exchange rate of USD currency in 2015 was about 13,500 IDR to 1 USD.

Note 3. Exchange rate of USD currency in 2000 was about 4,665 IDR to 1 international dollar. 


\section{Macrothink}

Journal of Asian Development

ISSN 2377-9594 2019, Vol. 5, No. 1

Note 4. Exchange rate of USD currency in 2016 was about 11,732 IDR to 1 international dollar.

\section{Copyright Disclaimer}

Copyright for this article is retained by the author(s), with first publication rights granted to the journal.

This is an open-access article distributed under the terms and conditions of the Creative Commons Attribution license (http://creativecommons.org/licenses/by/4.0/). 